\title{
Europeanisation as de-politicisation, crisis as re-politicisation: the case of Greek foreign policy during the Eurozone crisis
}

\author{
Dr Angelos Chryssogelos
}

\begin{abstract}
:
This article examines the Europeanisation of Greek foreign policy during the Eurozone crisis. It proposes a conceptualisation of Europeanisation as de-politicisation and argues that national foreign policy in the EU under crisis has been re-politicised, i.e. it is increasingly contested among electorates while elites are becoming more conscious of the legitimacy deficits created when national policymaking is exercised primarily via EU institutions. In this context, Europeanisation of foreign policy becomes reflexive, i.e. it is subject to more active scrutiny by public opinion while foreign policy making reflects elites' effort to manage increasingly fractious state-society relations. The article also differentiates between two types of re-politicisation of foreign policy: nationalist and societal politicisation, both of which were evident in Greece during the crisis years. Beyond these concepts, the article highlights more generally the importance of national party politics for foreign policy Europeanisation, a dimension mostly neglected in the literature.
\end{abstract}

Keywords: Europeanisation; foreign policy; Greece; political parties; crisis

Version published online in Journal of European Integration, 5 December 2018

https://doi.org/10.1080/07036337.2018.1544249

\section{Introduction}

On 17 June 2018 Greek Prime Minister Alexis Tsipras met Prime Minister Zoran Zaev of the Former Yugoslav Republic of Macedonia (FYROM) on the border of the two countries to sign an agreement resolving the so-called name dispute between them. The ceremony was attended by the EU commissioners for external relations and enlargement, signalling its importance for EU interests in the Western Balkans. But while Tsipras enjoyed the compliments of the EU and European leaders, the agreement itself remains very unpopular in Greece. In early 2018 hundreds of thousands of Greeks had demonstrated against the beginning of negotiations with FYROM. At the time of signing the agreement, most opinion polls in Greece recorded a strong popular majority against it.

That Tsipras, once the consummate populist (Stavrakakis and Katsambekis 2014), signed an agreement that fully aligns with EU foreign policy priorities but is strongly resisted by Greek public opinion brings back into focus the question of the Europeanisation of Greek foreign policy. Greek foreign policy Europeanisation was a topic that attracted much scholarly attention before the Eurozone crisis, but interest in it receded markedly thereafter. This reflects a reduced interest in foreign policy Europeanisation in EU studies more generally. The last major volume on the topic covers the period up to the Eurozone crisis (Wong and Hill 2012), and recently only one collection of articles examines the impact of the crisis on foreign policy Europeanisation (Stavridis, 
Tsardanidis, and Christou 2015). This article aims to rekindle research interest in this topic by examining the question of how Europeanisation of Greek foreign policy evolved since the Eurozone crisis erupted in 2009.

Greece is a good case for the study of the effect of the crisis on foreign policy Europeanisation. It is a country where foreign policy has traditionally been politically and socially salient; an impressive turn towards Europeanisation took place in the late-1990s; and the Eurozone crisis has had the most dramatic effect on domestic politics. At the same time, the Greek case offers the opportunity to address important, but relatively neglected, questions in the Europeanisation literature like the role of party politics for Europeanisation and the political impact of the economic crisis (Falkner 2016).

This article conceptualises Europeanisation as de-politicisation of national policymaking, and foreign policy Europeanisation as a dimension of a broader phenomenon of state transformation in Europe, whereby EU integration provides a venue for national elites to conduct policy beyond the reach of national political communities and their scrutiny. The Eurozone crisis however exacerbated tensions and legitimacy gaps between the state and society that European integration had long fostered, repoliticised the issue of the national alignment and in some cases even of membership of the EU, and as a consequence upset Europeanisation in a number of policy areas, including foreign policy.

In Greece the main avenue for the re-politicisation of its relationship with the EU, and therefore of aspects of its foreign policy as well, has been the radical upending of its representative politics during the crisis - both in respect of the relationship between the political system and the people, and of the patterns of party competition as such. The article argues, in short, that the ideological makeup and attitudes towards the EU of governing parties determined the ebbs and flows of Europeanisation over this period.

Pro-EU governments in 2010-14 pursued more assertively national goals, conscious of the need to boost their profile towards Greek public opinion and to justify their alignment with a now unpopular EU. SYRIZA's government in the first half of 2015 put foreign policy to the service of its renegotiation with the Eurozone, threatening a deep break between Greek foreign policy and EU priorities. But in this period there were also areas of Greek foreign policy that, intentionally or inadvertently, were sheltered from politicisation. These cases of preserved Europeanisation facilitated the overall re-Europeanisation of Greek foreign policy after July 2015. This reEuropeanisation however is more reflexive and precarious than what existed before the crisis: even though Greeks do not challenge the country's alignment with Europe, they are more prone to question the dilution of national interests in salient issue areas this often necessitates. From the perspective of governing elites Europeanisation is no longer a tool of de-politicisation of foreign policy but the exact opposite, a constant risk of public re-politicisation that requires permanent political management.

The article begins with a theoretical discussion of foreign policy Europeanisation as depoliticisation, and the implications for the study of national foreign policies in the EU. It will then 
present the historical background of Europeanisation of Greek foreign policy. The bulk of the analysis presents the successive phases of Greek foreign policy's relationship with the EU that mirror the fluctuations in the political contestation of the relationship between Greece and the EU during the crisis. The final section summarises and discusses implications for the study of foreign policy Europeanisation.

\section{Europeanisation as de-politicisation, crisis as re-politicisation}

Europeanisation describes the impact of the EU on national institutions, policymaking and politics (Featherstone and Radaelli 2003; Olsen 2002). Foreign policy can also become Europeanised. Despite EU foreign policy remaining formally an intergovernmental area (Wong and Hill 2012, 218), it is a dense field of norms and cooperation practices between national and EU officials that affect the design and conduct of national foreign policies (Alecu de Flers and Müller 2012; Smith 2004; Wong and Hill 2012, 9). This combination of formal intergovernmentalism and institutionalised cooperation between national actors makes foreign policy Europeanisation subject to complexity and contingency (Wong and Hill 2012, 4-5).

An aspect of Europeanisation is how national diplomats have become accustomed to informing their EU partners about their views and movements - the 'coordination reflex' (Glarbo 1999). National foreign policy style, rhetoric and instruments can also come to reflect the core EU norm of pacified and rules-based international politics. Member states turn to the EU for collective solutions to challenges they would otherwise tackle alone (Economides 2005; 472-482; Moumoutzis 2011, 619), and because they see them as beneficial for national interests (Moumoutzis 2011, 622-624; Tsardanidis and Stavridis 2005). EU impact on national foreign policies is deepest when national foreign policies become sincere propagators of EU interests and values - 'socialisation' (Larsen 2014, 371). Socialisation is most evident in interactions in bureaucratic settings among experts, especially in Brussels (Wong and Hill 2012, 10).

But Europeanisation is not only a process of policy change. It is also a transference of policymaking away from the nation-state, and thus implies a deep transformation of statehood in Europe. This transformation has been conceptualised by Bickerton as the passage from the nation-state to the 'member state' (Bickerton 2011, 2015). Its key characteristic is the insulation of member state elites from domestic societal constraints. Whereas in the nation-state sovereignty is exercised with reference to a territorially defined political community, member states legitimise their rule with reference to their elites ${ }^{11}$ participation in transgovernmental policymaking networks (Bickerton 2015, 54-55; for a general critique of the challenges to national representative politics caused by Europeanisation, see Mair 2013).

Looking especially at foreign policy, Bickerton goes beyond the empirical and analytical distinction and debate in much of the literature on Europeanisation as either pursuit of national interests or sincere adherence to EU norms. In fact, the two can coexist in the practice of national foreign policy in the EU. Member states always have their preferences and interests, while close cooperation in EU institutions means that national policymakers will always internalise at least some of the norms and practices they share with their colleagues. The important point rather is 
that the very pursuit of national interests is transformed by routines and interaction at the expert level (Bickerton 2011, 180-181), and that supranational policymaking and socialization challenges the legitimacy and representativeness of national politics in Europe.

Europeanisation of foreign policy raises the normative question of whether European integration helps national elites escape domestic scrutiny and emasculates political contestation at the national level (see also the discussion of the 'double democratic deficit' specific to foreign policy in Stavridis, Tsardanidis, and Christou 2015, 5). This depoliticization causes a 'state of disequilibrium' in the EU: as representative politics cannot hold political and administrative elites sheltered in settings of supranational deliberation accountable, popular disenchantment with integration increases. In this context, one can view the governance crises of recent years in the EU (Eurozone, refugee, Brexit etc.) as expressions of this state of disequilibrium, i.e. as crises of state transformation that politicise the passage from the nation-state to the member state (Bickerton, Hodson, and Puetter 2015).

To conceptualise the passage from de- to re-politicisation, the work of Michael Zürn $(2004,2014)$ is useful. He has argued that 'political denationalisation' - policymakers cooperating in settings above the nation-state and beyond the control of national democratic communities - inevitably creates 'its own potential for resistance'. The reason is that the legitimacy consequences of denationalisation necessarily bring about an 'unintended' process of 'self-confrontation' and reflection by political communities (Zürn 2004, 275-277). Thus, any process of denationalisation (like Europeanisation) carries within it the seeds of its own re-politicisation - even more so, one could argue, when major governance crises such as the ones the EU went through in recent years accentuate the awareness of the public at large of these legitimacy implications.

Re-politicisation can take two forms. 'Transnational resistance' pushes for democratization of supranational policymaking, accepting that some issues require deeper international cooperation (Zürn 2004, 279-282). 'National resistance' on the other hand pushes for return of control to the national level, the historical locus of political contestation (Zürn 2014, 64-66). National resistance is centred less around the preoccupation of nation-states with sovereignty, than around national societies aiming to regain control from national elites that have become internationalised. Thus, opposition to internationalisation becomes a clash between society and state, which makes societal repoliticisation overlap significantly with populism (Zürn 2004, 283 285; on populism generally see Laclau 2005).

Although Zürn's focus is on societal re-politicisation, popular demands for national repoliticisation can also be woven around a classical nation-state sovereignty frame. I call this nationalist re-politicisation. The relationship between the two is analogous to the one between nationalism and populism. Despite overlaps (their focus on the sovereignty of the political community), they differ on how they view the relationship between state and society: nationalism views it as complementary and necessary for the nation's survival, whereas populism sees it as inherently oppositional. ${ }^{2}$ Put yet differently, the difference between nationalist and societal politicisation is whether a political community opposes specific policies under the pressure of internationalisation (such as the dilution of rigid formulations of the national foreign 
policy interest in order to accommodate broader EU foreign policy priorities), or it challenges the very legitimacy of internationalised state elites and the state's membership of the EU as such.

The question of politicisation points to the role of domestic politics as a filter of EU impact on national settings. The role of party politics is generally acknowledged in the literature on foreign policy Europeanisation (Alecu de Flers and Müller 2012, 23-24; Smith 2004, 752), but has received limited attention in practice (Carbone and Quartapelle 2015, 4). This could be because until recently party politics in EU countries revolved around a centripetal right-left competition that did not facilitate contestation of Europeanisation (Wong and Hill 2012, 216-217). But the Eurozone crisis has caused popular reactions against elites (Kaldor and Selchow 2013) and realigned party competition in various countries, Greece being the most prominent example among them, around the question of their relationship with the EU (Katsanidou and Otjes 2016). Under these conditions, Europeanisation is increasingly subject to popular scrutiny and politicisation (Stavridis, Tsardanidis, and Christou 2015, 7).

This focus on the public, societal and representative dimension of Europeanisation is not meant to dismiss the importance of prevalent debates in the literature on foreign policy Europeanisation like rationality vs. socialisation (Alecu de Flers and Müller 2012, 25-27). The point rather is that, under conditions of politicisation, Europeanisation becomes increasingly entangled and contingent upon its societal and political context. The single-minded focus of most of the literature on practices, norm internalisation, bureaucratic interactions etc. presumes an effective depoliticization of foreign policy at the popular level and/or a low salience of the foreign policy issues examined. Without challenging the findings of this literature, the argument here is that, as the popular challenge to Europeanisation of the state and its elites increases, Europeanised foreign policy opens up to influences outside the confines of policymaking and bureaucracy.

Re-politicisation of Europeanised foreign policy unfolds along a continuum that mirrors the degree of politicisation of a state's alignment with the EU at the societal level. Taking the practice of foreign policy making in EU institutions under conditions of de-politicisation on the mass level - the implicit assumption of most of the literature on foreign policy Europeanisation - as the starting point, this continuum proceeds rightwards as depicted in Figure 1.

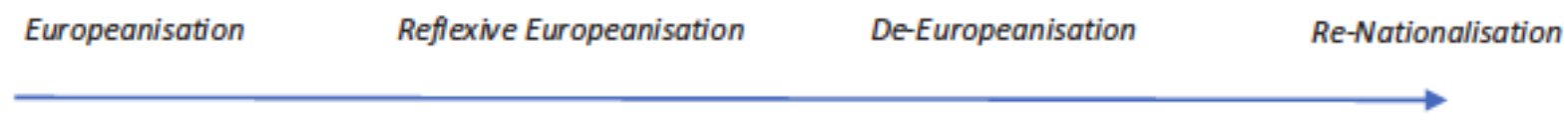

Policymaking / Elites

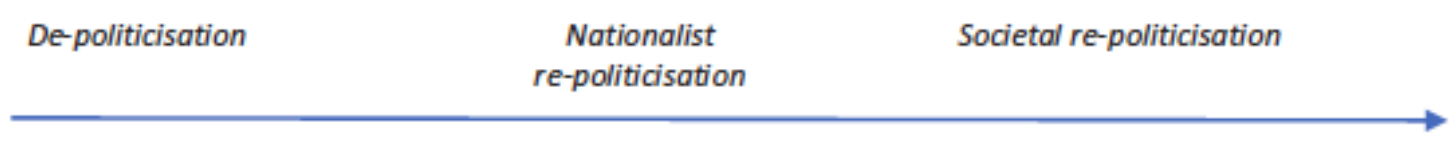

Contestation / Electorate, public opinion

Figure 1. Relationship between Europeanisation and politicisation. 
Developments like the Eurozone crisis induce both elites and political communities to problematise the state's relationship with the EU. As a first step in re-politicisation, political communities scrutinise more closely the alignment between national and EU goals and priorities (nationalist re-politicisation). Elites on the other hand become more self-aware of their conduct in supranational governance networks as they balance the exigencies of policymaking in the EU and the demands of more mobilised public opinions. In this context foreign policy Europeanisation becomes reflexive. Europeanised foreign policy is possible here, especially in non-salient areas, but in more politicised issues the degree and direction of Europeanisation will be the outcome of a conscious strategy by governments to, invariably, draw political benefits from alignment with Europe, neutralise public suspicion, outflank the opposition, or create leverage in other issue-areas (e.g. the economy) vis-à-vis the EU.

This understanding of Europeanisation shares with some of the Europeanisation literature (e.g. Tsardanidis and Stavridis 2005) the assumption of rationality of state actors. But the difference is in the stimuli and objectives of these rationally behaving state actors. When Europeanisation becomes reflexive, state elites do not simply pursue the national interest by engaging pragmatically with EU procedures and norms, but are conscious of how their conduct in EU institutions can impact their political fortunes or affect the standing of the EU in the eyes of the political community they represent. This is a crucial difference in the kind of rationality employed: the EU becomes less a tool of de-politicisation for elites to pursue state interests beyond the scrutiny of democratic communities (Bickerton 2011), and more a risk of public re-politicisation that elites must manage while conducting foreign policy in the EU.

By the same token, the argument here does not question that deep socialization processes, learning, deliberation etc. may be taking place among foreign policy makers and experts in EU settings (Alecu de Flers and Müller 2012, 27-31). The point rather is that the context within which these processes take place changes significantly once political communities become more inquisitive about the implications for representation and democratic control if key functions of the nation-state run through supranational and transgovernmental governance networks. As a result, the outcomes of Europeanisation will be subject to public scrutiny and critique by Eurosceptic or populist parties much more than in the past. ${ }^{3}$

Further to the right of our figure, reflexive Europeanisation can become even more constraining, as nationalist re-politicisation turns into societal re-politicisation that challenges not just the alignment between national interests and European commitments, but the very legitimacy of the Europeanised state. This is the area where populists question the logic of the Europeanised member state. Societal re-politicisation may cause reflexive Europeanisation to degenerate into de-Europeanisation, a departure from EU foreign policy norms and practices that had seemed until then relatively well internalised (Stavridis, Tsardanidis, and Christou 2015; Wong and Hill 2012 , 214). From here, a member state can continue to move rightwards to full foreign policy renationalisation.

Of course, not all foreign policy issues will be located on the starting point of perfect depoliticisation. The model presented here does not address only the politicisation of fully 
Europeanised policy areas. Rather, the argument is that politicization causes policies of various degrees of Europeanisation and salience to move rightwards in relative terms along the Europeanisation continuum. Foreign policy issues that were long effectively de-politicised and managed via the EU may become again object of partisan contestation at the national level (nationalist politicisation). Traditionally salient foreign policy issues (such as the FYROM name issue for Greece) that were never perfectly de-politicised can be even more closely scrutinised under conditions of reflexive Europeanisation, increasing public pressures to de-Europeanise the state's conduct. And issue areas such as energy security may remain largely nationalised despite EU efforts at closer cooperation (Wong and Hill 2012, 222), but politicisation may make them even more salient for public opinion or cause them to be instrumentalised by political actors who challenge Europeanisation (societal politicisation).

\section{The pre-crisis years: Europeanisation of Greek foreign policy as de-politicisation}

For the first 15 years of its EEC/EU membership, Greece projected its difficult foreign policy issues on to Community proceedings. After 1996 a change of guard in the ruling PASOK party kickstarted a new approach towards the EU, which also entailed a reassessment of foreign policy. From the beginning, Europeanisation of Greek foreign policy was closely associated to a broader project of domestic 'modernisation' of the Greek state (Economides 2005, 475-476) and its deeper embedding in European integration (Ioakimidis 2000). Europeanisation also entailed change in administrative practices, calling for a more rationalised functioning of the foreign policy bureaucracy that traditionally in Greece was marred by partisanship and inefficiencies (Tsardanidis 2015).

In the Helsinki European Council of December 1999 Greece accepted Turkey as EU accession candidate (Blavoukos and Bourantonis 2012). This change was presented as a sophisticated way to pursue the national interest, as Greece would use EU leverage to apply conditionality on Turkey (Tsardanidis and Stavridis 2005). At the time a majority of Greek public opinion was opposed to Turkish EU membership, despite Greece having gained a promise that Cyprus could accede into the EU (Tsakonas 2010, 216). Yet the prospect of domestic change and reforms via the EU was so popular that a foreign policy presented as a precondition for Greece's entry to the Eurozone was easily accepted (Chryssogelos 2015).

Europeanisation of Greece's Balkan policy, whereby it saw its political and security considerations best served by the Western Balkans' EU accession, was less controversial but still entailed tensions. Given its historically complicated relations (informed not least by persistent popular suspicion) with Albania, Kosovo and FYROM, the choice to pursue relations with the Balkans via the framework of EU enlargement (Mavromatidis 2010, 55) contributed to the de-politicisation of this part of Greek foreign policy as well.

Greece's alignment with Europe during the 2000s was supported by a convergent and stable twoparty system dominated by pro-EU parties. The competition between the centre-left PASOK and the centre-right New Democracy effectively pre-empted any contestation of the domestic agenda of modernisation and the external agenda of Europeanised foreign policy (Chryssogelos 
2015). While the foreign policy Europeanisation agenda was initiated in earnest by a socialdemocratic wing within PASOK, it quickly appealed to New Democracy politicians as well as administrative and intellectual elites with its promise of more effective management of Greece's external relations beyond the pressures of what was seen often as overtly nationalistic and irrational public opinion (Tsardanidis 2015, 63). This equilibrium between domestic and foreign policy Europeanisation however was about to be shattered with the advent of the crisis in 2009.

\section{The emergence of reflexive Europeanisation and societal politicisation, 2010-14}

In October 2009 PASOK won a snap election and formed a new government led by George Papandreou, foreign minister in the governments that between 1996 and 2004 instituted Greek foreign policy's turn towards Europe. Papandreou requested in April 2010 a bailout loan from the Eurozone and the IMF. This unleashed a rabid contestation not just of austerity but of Europeanised state-society relations more generally. The focus of this contestation was the economy, but it also reflected demands for national sovereignty (Halikiopoulou, Nanou, and Vasipoloupou 2012) and popular emancipation (Stavrakakis and Katsambekis 2014). Austerity made the Greek public turn against the EU very quickly (Clements, Nanou, and Verney 2014).

In the first phase of the crisis (2010-11), contestation of austerity took place within the competition between PASOK and New Democracy. The new leader of New Democracy Antonis Samaras rejected the bailout program Papandreou brought to parliament in 2010. For 18 months in 2010-11, New Democracy became the main exponent of the anti-memorandum [bailout] sentiment in Greece. But Samaras' career was also inextricably tied with foreign policy: as foreign minister in the early 1990s he put forth a hard-line policy against FYROM on the name-issue that led to his split from New Democracy. As he aimed to veer New Democracy to the right, Samaras made the link between foreign policy and crisis explicit: in a debate in parliament in January 2011, in a stark articulation of nationalist re-politicisation of foreign policy, he warned Papandreou that he would reject compromises on foreign policy brought about by economic pressures. ${ }^{4}$

Papandreou on the other hand saw foreign policy as part of Greece's effort to remain anchored to Europe amidst the crisis. ${ }^{5}$ As one of the early exponents of Europeanisation, Papandreou was a sincere believer in its benefits. At the same time however, he believed that Greece making positive contributions to EU foreign policy could offset the country's rapid loss of international status. In this vain, Papandreou undertook foreign policy initiatives congruent with EU principles and priorities like re-energising bilateral dialogue with Turkey and meeting with FYROM's prime minister Gruevski. In this way, already a certain amount of reflexivity in Greek foreign policy began to be introduced. ${ }^{6}$

During this period societal politicisation took place outside the party system, in the big popular mobilisation against austerity and the political elites and their identification with the EU (Aslanidis and Marantzidis 2016). Within this milieu new foreign policy conceptions began to hatch where disengagement from the EU was seen as a precondition for the end of austerity and the re-establishment of social sovereignty in Greece. Activists of both left-wing and right-wing background called for the strategic reorientation towards non-Western powers like Russia, or the 
intensification of exploitation of energy resources in the Aegean and Ionian seas in order for Greece to escape its financial quandary.

After the double elections of 2012, the anti-austerity sentiment migrated from the streets to the party system, which was radically realigned between a pro-EU government led by Samaras of (now pro-austerity) New Democracy and a much diminished PASOK,and two populist antiausterity parties, SYRIZA on the left and the Independent Greeks (ANEL) on the right (Voulgaris and Nicolacopoulos 2014). In this party system, relations with the EU were a major stake of competition. The opposition of SYRIZA and ANEL did not only scrutinise the impact of EU membership on Greek interests, but also harboured ideas of strategic disengagement from Europe as precondition for the end of Greece's economic and political subjugation.

In response to this re-politicisation of EU membership, the Samaras government became more aware of the need to emphasise that alignment with the EU produced tangible benefits for Greece. ${ }^{7}$ At the same time, foreign policy initiatives that strengthened Greece's position in its region were seen as a way to counter-balance its rapid loss of international status. For example, Samaras continued the strategic openings towards Israel that Papandreou had initiated in 2010 in response to the Turkey-Israel rift after the Mavi Marmara incident. Samaras engaged in an activist diplomacy in the Eastern Mediterranean, aiming to involve Israel in multilateral schemes that included also Cyprus and potentially Egypt. While he always stressed the importance of these initiatives for European security, he also embedded them in a narrative of a stronger Greece as an 'island of stability' in a region in turmoil. ${ }^{8}$

The openings towards Israel and the Eastern Mediterranean focused especially on energy security, an area that had been one of the touchstones of the anti-austerity mobilisation due to its potential for economic alleviation of austerity and alignment with Russia as a counterbalance to Greece's dependence on the EU. In response to the repoliticisation of Greece's relationship with the EU, energy became for the pro-EU governments of this period a way to demonstrate that the EU framework could indeed help Greece achieve its goals. At the same time, an activist energy policy played to the sentiments of a Greek public fascinated by geopolitical narratives of pipeline competition (Tsakiris 2014, 17).

Under Samaras, Greece aimed to position itself as an important transit country, as well as pursue opportunities both with EU-backed and Russia-backed pipeline projects. ${ }^{9}$ In some cases, the Greek government could showcase that an energy policy closely aligned with the EU delivered dividends. This was the case when the TAP pipeline favoured by Greece was chosen by Azerbaijan to transport its gas to Europe. In other cases, however, the tension between Greek and EU energy policy became palpable, particularly with regards to EU objections to Russian-backed projects (Tsakiris 2013). As an official involved in energy policymaking during this period put it, 'Europe is an arena of negotiation where you must pragmatically pursue your interests and strike bargains' ${ }^{10}$ For pro-EU parties the EU offered a framework where the importance of Greece as an energy player and a factor in the EU's energy security could be highlighted. ${ }^{11}$ 
In other policy areas the New Democracy-PASOK coalition saw little reward in proactive initiatives, for example towards the Balkans. During this time Greece did not depart from its support for the European perspective of the Balkans, but its approach became more selective and utilitarian. The coalition's policy focused on immediate concerns, like the blocking by a new Albanian government of the agreement signed by the two countries demarcating their maritime zones - again, an issue with economic implications as it affected Greece's capacity to exploit potential energy resources in the Ionian Sea.

In a different sense, the crisis also helped Greece to shelter itself from pressures associated with Europeanisation. With the EU interested mostly in Greece completing its reform program, the appetite for initiatives on other fronts, such as the FYROM name-issue, decreased. ${ }^{12}$ The consumption of Greece and its EU partners with the crisis contributed to Greece evading any pressure created by a ruling of the ICJ in late 2011 against Greece's veto of FYROM's entry to international organisations. ${ }^{13}$

In sum, in the first phase of the crisis the Europeanisation of the Greek polity was abruptly repoliticised, and this made the conduct of Greek foreign policy within the EU framework more self-conscious than in the past. Nationalist politicisation (questioning how EU pressures force Greece to dilute its foreign policy stances) was expressed in the party system by the anti-austerity parties of the time, New Democracy in 2010-11 and SYRIZA and ANEL in 2012-14. With regards to societal politicisation, ideas of disengagement from the EU for the sake of escaping austerity and re-establishing popular control were aired both by the anti-memorandum movement in 2010-11 and the populist opposition parties in 2012-14. In response, foreign policy by pro-EU governments became more deliberate. Numerous policy areas of low salience or technical nature remained de-politicised, but overall pro-EU governments of the time confronted with partisan polarisation and popular distrust carefully pursued foreign policy issues that promised tangible gains, allowing them to demonstrate both Greece's importance to its EU partners and the usefulness of the EU framework to the Greek public. ${ }^{14}$

\section{Economic renegotiation and the threat of de-Europeanisation, 2015}

The entry into government in January 2015 of an anti-austerity coalition of SYRIZA and ANEL opened a new period in the Greek crisis. The new coalition saw EU membership as a means through which Greek elites frustrated the will of the people - a typical case of societal repoliticisation of Greece's EU membership and the policy commitments this entailed. The economy was the main area of contention, but a mistrust of European constraints, norms and procedures became evident in a wide range of policy domains. Greece's antagonistic negotiation with the Eurozone culminated in a referendum in June 2015 , where more than $60 \%$ of Greeks rejected austerity despite the clear threat of eviction from the Eurozone.

The appointment of Nikos Kotzias by new prime minister Alexis Tsipras as foreign minister seemed to follow this logic of re-politicisation and scrutiny of Europeanisation. Kotzias had been a strong intellectual voice of the anti-austerity movement. He had scrutinised Greece's dependence on Europe and the West and had advocated an 'energetic and independent foreign 
policy' that would embrace the emerging powers of the international system (Kotzias 2010). This attitude dovetailed with SYRIZA's intention to explore new sources of financing and leverage visà-vis the EU, be it from Russia, China or elsewhere.

High-profile foreign policy initiatives of the SYRIZA-ANEL government that interlinked with its opposition to austerity, such as Tsipras' visit to Moscow in April 2015, dovetailed with Kotzias' earlier support for a more independent foreign policy. An area where the new government's moves were closely scrutinised was the question of EU sanctions against Russia over its occupation of Crimea. From early Kotzias made his dislike for the sanctions clear, generating questions as to whether Greece was considering turning to Russia if its economic renegotiation with the Eurozone stalled. ${ }^{15}$ In the end however, Greece did not veto common EU foreign policy decisions or actions during that period.

An area that the new government tried to use in its renegotiation with the EU was energy. This became evident in the visit of Alexis Tsipras to Moscow to meet with Vladimir Putin in April 2015. While Putin did not commit any serious sum of money to Greece, the most important agreement signed was Greece's participation in the new Turkish Stream pipeline project, which replaced South Stream as the main avenue of Russian gas into South-eastern Europe (Tagliapietra and Zachmann 2015). The minister for energy at the time was Panagiotis Lafazanis, leader of the antieuro faction of SYRIZA. The rhetoric of Lafazanis was explicitly antagonistic to the EU, ${ }^{16}$ and relevant EU policymakers were highly alarmed. ${ }^{17}$

It is interesting however that in areas that had little bearing over Greece's renegotiation, like the Balkans, Greece did not challenge the EU framework. Instead, Kotzias undertook initiatives towards the two Balkan countries that Greece had the most complicated relations with - FYROM and Kosovo. With FYROM, Kotzias established a dialogue process and a set of confidence building measures. He became the first Greek foreign minister to visit Skopje in 11 years in June 2015. He also became in July the first Greek foreign minister ever to visit Pristina (Maksimovic 2016, 1416).

Generally, Kotzias' Balkan policy demonstrated an impressive degree of continuity with Greek policies of the previous 15 years informed by the spirit of Europeanisation. This was evident for example in the reserved tone with which Greece responded to the heightened nationalist rhetoric of the Albanian government in 2016, which received wide press coverage in Greece (Maksimovic 2016, 13-14). Given challenges in the region, Kotzias' diplomacy was more careful than what an 'independent and forceful foreign policy' favoured by the anti-memorandum front's nationalist wing (present in ANEL, but also in parts of SYRIZA) would imply. One could say that here the crisis even mitigated re-politicisation: with attention squarely focused on these foreign policy issues that were interlinked with the economic renegotiation (energy, relations with Russia), Kotzias found space to pursue policies elsewhere that aligned with Greece's prior commitments to the EU framework and could have been more politicised in a different political context. 
It is doubtful that Kotzias' policies reflected a sincere socialisation in the tenets of Europeanisation more than his personal reading of how Greece could re-establish its influence in the Balkans. ${ }^{18}$ But his initiatives built on the insulation of Greece's Balkan policy from public pressures and even went against ideological positions inside his own governing coalition. Even though the cultivation of relations with Albania and FYROM dovetailed with the Greek left's historical opposition to nationalism in the region, Kotzias' overtures towards Kosovo contradicted earlier positions of SYRIZA against recognition of Kosovo's unilateral independence (SYRIZA 2015). Kotzias' initiatives during this period also contradicted ANEL's hard-line positions on relations with FYROM and Albania. ${ }^{19}$

Greece's Balkan policy in the first half of 2015 then is quite interesting. While it encompasses issues of potentially high public salience (chiefly the Macedonia name-issue, but also relations with Albania, Serbia and Kosovo), it remained largely de-politicised at a time of heightened politicisation of Greece's relationship with the EU in other issues. Unlike areas of foreign policy that were affected by societal politicisation - the challenge to Europeanisation in the name of democracy and the end of austerity - and therefore came close to de-Europeanisation (e.g. Greece's stance on EU sanctions against Russia), the new government's Balkan policy did not stray from the EU framework.

In sum, in the first half of 2015 various aspects of Greek foreign policy were affected by societal politicisation of the Greece-EU relationship. Areas that were relevant for the economic renegotiation, such as relations with Russia and energy policy, came the closest to deEuropeanisation. And of course, had Greece left the Eurozone and the EU after the July referendum most aspects of its foreign policy could have been fully re-nationalised. At the same time, it is important to note that the day-to-day conduct of Greek foreign policy in EU institutions continued in most issues unaffected from the hyper-politicisation of the time, ${ }^{20}$ Greece did not block any EU common positions in controversial issues, and in areas like the Balkans the political initiatives of the new government even dovetailed with the ideas and interests of the EU. On aggregate, the Europeanisation of Greek foreign policy in this period was maintained although it was clearly of the reflexive kind, growing out of considerations and strategies that had little to do with EU norms and practices and more with domestic ideological or personal priorities.

\section{Return to reflexive Europeanisation and SYRIZA normalisation, 2015-18}

After Tsipras accepted a new austerity package in July 2015, the faction under Lafazanis left SYRIZA and formed a new anti-austerity party that failed to enter parliament in the September 2015 snap elections. The SYRIZA-ANEL coalition was re-elected, only this time accepting the same limitations on national independence as previous pro-EU governments. Just like these governments, an emasculated Tsipras realised that he had to start showcasing that the EU could benefit Greek foreign policy after all. It is ironic that one of the first areas where this happened was in energy, in previous years one of the most politicised areas of foreign policy by the antiausterity camp: in May 2016 for example Tsipras inaugurated the Greek branch of TAP in Thessaloniki, with EU officials present. The change in tone was drastic, and as a high-ranking EEAS official noted, 'Tsipras read Samaras' speech at the inauguration'. ${ }^{21}$ 
Greek foreign policy after the summer of 2015 cannot be understood in isolation from SYRIZA's effort to carve out a new niche for itself as a left-wing party operating in the asphyxiating framework of bailouts and austerity. This means that Greek foreign policy remains within the broad confines of Europeanisation, but in a manner contingent on the salience of various foreign policy issues and the domestic needs of Tsipras and his party. In times of emergency, such as the refugee crisis of 2015-16, Tsipras was forced to appeal to 'universal European values' in asking for more assistance from the EU and relying on its negotiating heft to convince Turkey to cooperate in the management of migrant flows. Other times however his government could look to bolster its popular patriotic credentials through foreign policy, such as when the Cyprus reunification talks collapsed in 2017, a development attributed by some to Kotzias' intransigent stance during the negotiations. ${ }^{22}$

In this context, the pro-European references of Tsipras and Kotzias when advocating for the agreement on the name-issue with FYROM in June 2018 are not necessarily indication of full and sincere Europeanisation. The impetus for the agreement came from the change of government in Skopje and the emergence of a more conciliatory leadership in FYROM. This created the space for SYRIZA to pursue, despite pushback from Greek public opinion, an agreement for a host of reasons: Tsipras' hope of further normalising his international presence among Greece's partners, the hope that the agreement would create a split in the opposition centre-left and New Democracy, Kotzias' ideas about the need for Greece to re-establish its leading position in the Balkans that he had already acted upon since $2015,{ }^{23}$ and implementing one of the long-standing foreign policy positions of the Greek left. For as much as Tsipras and Kotzias' initiative on FYROM agreed with EU priorities in the region, the variety of reasons behind that decision makes this yet another example of reflexive Europeanisation.

The rallies in Athens and Thessaloniki in February 2018 against negotiations with FYROM and the persistent demonstrations in Northern Greece after the agreement was signed showcase on the other hand that Europeanisation of foreign policy remains subject to heightened public politicisation and scrutiny in Greece. Again, the context of the crisis is relevant: with Greek politics dominated by two parties (SYRIZA and New Democracy) that now accept the fundamentals of EU and Eurozone membership, there is very little space for societal politicisation, i.e. the political expression of discontent with Greece's EU membership. Instead, foreign policy provides ample opportunities for nationalist politicisation, acting as a highly symbolic and charged issue area where Greeks can challenge the adaptation by Europeanised elites of Greek goals, interests and stances to EU priorities.

\section{Conclusion}

This article has argued that the study of foreign policy Europeanisation can benefit from an understanding of Europeanisation as de-politicisation. I have put forward the concept of reflexive Europeanisation, under which political communities enquire more intensely whether the national interest is served by EU foreign policy and elites become more sensitive to the need to publicly legitimate alignment with the EU. Reflexive Europeanisation does not necessarily mean 
deviation from EU goals and policies. But as the analysis here shows, in a more politicised relationship between elites and people and between member states and the EU, the issues, timing and degree to which national foreign policies will align with the EU will be increasingly, and often unpredictably and erratically, contingent on factors like the ideological outlook of governing parties or short-term tactical considerations of politicians dealing with more energised, vigilant and suspicious electorates.

The article also distinguished between two types of re-politicisation of foreign policy in the EU: nationalist re-politicisation, which refers to the increase of scrutiny by political communities over how national interests are served in the EU; and societal repoliticisation, where societies question the very legitimacy of the Europeanised state. The article applied these concepts primarily to areas of already high public salience in Greek foreign policy (relations with Turkey, the Western Balkans, energy security etc.), and in so doing showcased the importance for future research to more actively address the public and societal dimensions of foreign policy Europeanisation. Of course, future analyses may use these concepts to evaluate the Europeanisation of less salient, technical or bureaucratic aspects of foreign policy under repoliticisation as well (see e.g. Tsardanidis 2015).

In terms of empirical findings, the article argued that Greek foreign policy witnessed a move to reflexive Europeanisation in the first years of crisis under pro-EU governments (2010-14). Forced to implement austerity and faced with rising public Euroscepticism, governments in that period emphasised domestically their pursuit of the national interest and the importance of the EU for achieving national goals, while aiming to raise and leverage Greece's international standing visà-vis its creditors. With the entry in office of a populist government in 2015 that aimed to politicise the terms of Greece's EU membership, aspects of foreign policy experienced a more radical movement towards de-Europeanisation. However, after the signing of a new bailout in July 2015, Greek foreign policy moved back towards re-Europeanisation. Yet this is not the largely depoliticized Europeanisation of the pre-crisis years, but a reflexive Europeanisation highly contingent on the interlocking dynamics of domestic party competition and the fluctuations of the political relationship between Greece and the EU.

In conclusion, the arc of the crisis pushed Greek foreign policy to the precipice of renationalization and then back to reflexive, and therefore contingent and contradictory, Europeanisation. In the words of one Greek diplomat: 'it was the crisis that made SYRIZA, and it was the crisis that tamed it'. ${ }^{24}$ In so doing however, the crisis has untamed again the Greek people as a factor of foreign policy. 


\section{Notes}

1. Elites here can refer to technocrats and bureaucrats, as described in the literature on 'intensive transgovernrmentalism' (Wallace and Wallace 2007); or elected political leaders, as described in the analysis of the 'new intergovernmentalism' in the European Council (Puetter 2014).

2. On the relationship and differences between populism and nationalism, see De Cleen and Stavrakakis (2017).

3. Interview with EU diplomat, London, 8 May 2015.

4. Speech of Antonis Samaras in Parliament on foreign policy, 24 January 2011. Available at https://www.youtube.com/watch?v=gtvzJX9fntg (accessed 23 June 2017).

5. Interview with Greek diplomat, Athens, 15 June 2016.

6. Interview with Greek diplomat, Athens, 13 June 2016.

7. Interview with Greek diplomat, Athens, 16 June 2016.

8. See e.g. Samaras' statements (in Greek) after his meeting with Angela Merkel in Berlin, 23 September 2014. Available at https://primeminister.gr/2014/09/23/12940, accessed 31 July 2018.

9. Interview with Greek diplomat, Athens, 16 June 2016.

10. Interview with Greek energy policymaker, Athens, 14 June 2016.

11. Interview with Greek foreign policy expert, Athens, 15 June 2016. This was emphasised e.g. by Samaras in his meeting with Merkel, where he also stressed the importance of Greece's own energy findings. See fn 14.

12. Interview with diplomat, FYROM mission to the EU, Brussels, 9 May 2016. Interview with EEAS official, Brussels, 13 May 2016.

13. Interview with Greek diplomat, Athens, 15 June 2016.

14. Interview with Greek diplomat, Athens, 13 June 2016.

15. 'Greece Delays EU Agreement on Russia Sanctions', The Guardian, 29 January 2015.

16. Sarantis Michalopoulos, 'Athens opposes EU energy strategy, blocks privatisations', Euractiv.com, 20 March 2015.

17. Interview with DG ENER official, Brussels, 12 May 2016.

18. Interview with Greek diplomat, Athens, 15 June 2016.

19. Interview with DG NEAR official, Brussels, 12 May 2016.

20. Interview with Greek diplomat, Athens, 13 June 2016.

21. Interview with EEAS official, Brussels, 31 May 2016.

22. Sara Stefanini, 'Greek Minister Blamed for Derailing Cyprus Talks', Politico.eu, 15 January 2017. https://www.politico.eu/article/greek-minister-blamed-for-derailingcyprus-

reunification-talks-kotzias/, accessed 2 August 2018.

23. Interview of Nikos Kotzias on Greek public TV, 29 January 2018. Available at https://www. youtube.com/watch?v=zgJUVlcss_M (accessed 22 February 2018).

24. Interview with Greek diplomat, Athens, 13 June 2016.

\section{Acknowledgments}

The research for this article was supported by a National Bank of Greece postdoctoral research grant. An earlier version was published as GreeSE Working Paper no. 118 by the Hellenic Observatory of the LSE. The author would like to thank Spyros Economides, Kevin Featherstone, an anonymous reviewer of the working paper and two anonymous reviewers of this article for helpful comments and suggestions for improvement. Special thanks are due to all diplomats and policymakers who kindly accepted to be interviewed for this project. All errors of interpretation and omission are the author's sole responsibility. 


\section{References}

Alecu de Flers, N., and P. Müller. 2012. "Dimensions and Mechanisms of the Europeanisation of Member State Foreign Policy: State of the Art and New Research Avenues." Journal of European Integration 34 (1): 19-35. doi:10.1080/07036337.2011.566330.

Aslanidis, P., and N. Marantzidis. 2016. "The Impact of the Greek Indignados on Greek Politics." Southeastern Europe 40 (2): 125-157. doi:10.1163/18763332-04002001.

Bickerton, C. J. 2011. "Towards a Social Theory of EU Foreign and Security Policy." Journal of Common Market Studies 49 (1): 171-190. doi:10.1111/j.1468-5965.2010.02134.x.

Bickerton, C. J. 2015. "A Union of Member States." In The New Intergovernmentalism: States and Supranational Actors in the Post-Maastricht Era, edited by C. J. Bickerton, J. Chris, D. Hodson, and U. Puetter, 51-72. Oxford: Oxford University Press.

Bickerton, C. J., D. Hodson, and U. Puetter. 2015. "The New Intergovernmentalism and the Study of European Integration." In The New Intergovernmentalism: States and Supranational Actors in the Post-Maastricht Era, edited by C. J. Bickerton, J. Chris, D. Hodson, and U. Puetter, 1-48. Oxford: Oxford University Press.

Blavoukos, S., and D. Bourantonis. 2012. "Policy Entrepreneurs and Foreign Policy Change: The Greek-Turkish Rapprochement in the 1990s." Government and Opposition 47 (4): 597-617. doi:10.1111/j.1477-7053.2012.01376.x.

Carbone, M., and L. Quartapelle. 2015. "Italy's Development Policy and the Domestic Politics of Europeanisation: Why Europe Matters so Little." European Politics and Society 17 (1): 42-57. doi:10.1080/23745118.2015.1075766.

Chryssogelos, A. 2015. "Foreign Policy Change in a Polarised Two-Party System: Greece and Turkey's EU Candidacy." Southeast European and Black Sea Studies 15 (1): 19-36. doi:10.1080/ 14683857.2014.1002293.

Clements, B., K. Nanou, and S. Verney. 2014. "We No Longer Love You, but We Don't Want to Leave You': The Eurozone Crisis and Popular Euroscepticism in Greece." Journal of European Integration 36 (3): 247-265. doi:10.1080/07036337.2014.885753.

De Cleen, B., and Y. Stavrakakis. 2017. "Distinctions and Articulations: A Discourse Theoretical Framework for the Study of Populism and Nationalism." Javnost 24 (4): 301-319. doi:10.1080/ 13183222.2017.1330083.

Economides, S. 2005. "The Europeanisation of Greek Foreign Policy." West European Politics 28 (2): 471-491. doi:10.1080/01402380500060528. 
Falkner, G. 2016. "The EU's Current Crisis and Its Policy Effects: Research Design and Comparative Findings." Journal of European Integration 38 (3): 219-235. doi:10.1080/07036337.2016.1140154.

Featherstone, K., and C. M. Radaelli, eds. 2003. The Politics of Europeanisation. Oxford: Oxford University Press.

Glarbo, K. 1999. "Wide-Awake Diplomacy: Reconstructing the Common Foreign and Security Policy of the European Union." Journal of European Public Policy 6 (4): 634-651. doi:10.1080/ 135017699343513.

Halikiopoulou, D., K. Nanou, and S. Vasipoloupou. 2012. "The Paradox of Nationalism: The Common Denominator of Radical Right and Radical Left Euroscepticism." European Journal of Political Research 51 (4): 504-539. doi:10.1111/j.1475-6765.2011.02050.x.

loakimidis, P. C. 2000. "The Europeanisation of Greece: An Overall Assessment." South European Society and Politics 5 (2): 73-94. doi:10.1080/13608740508539603.

Kaldor, M., and S. Selchow. 2013. “The 'Bubbling Up' of Subterranean Politics." Journal of Civil Society 9 (1): 78-99. doi:10.1080/17448689.2013.784501.

Katsanidou, A., and S. Otjes. 2016. "How the European Debt Crisis Reshaped National Political Space: The Case of Greece." European Union Politics 17 (2): 262-284. doi:10.1177/ 1465116515616196.

Kotzias, N. 2010. Greek Foreign Policy in the 21st Century. For a New, Energetic, Democratic, Patriotic Strategy in the Time of Globalisation. Athens: Kastaniotis (in Greek).

Laclau, E. 2005. On Populist Reason. London: Verso.

Larsen, H. 2014. "Discourses of State Identity and post-Lisbon National Foreign Policy: The Case of Denmark." Cooperation and Conflict 49 (3): 368-385. doi:10.1177/0010836713495000.

Mair, P. 2013. Ruling the Void: The Hollowing of Western Democracy. London: Verso.

Maksimovic, M. 2016. “Greece Returns to the Balkans? Assessing Greece's Western Balkan Policy under SYRIZA-led Government." Working Paper no. 14. Leipzig: Graduate Centre Humanities and Social Sciences, Research Academy Leipzig.

Mavromatidis, F. 2010. "The Role of the European Union in the Name Dispute between Greece and FYR Macedonia." Journal of Contemporary European Studies 18 (1): 47-62. doi:10.1080/ 14782801003638703.

Moumoutzis, K. 2011. "Still Fashionable yet Useless? Addressing Problems with Research on the 
Europeanisation of Foreign Policy." Journal of Common Market Studies 49 (3): 607-629. doi:10.1111/j.1468-5965.2010.02146.x.

Olsen, J. P. 2002. "The Many Faces of Europeanisation." Journal of Common Market Studies 40 (5): 921-952. doi:10.1111/1468-5965.00403.

Puetter, U. 2014. The European Council and the Council. New Intergovernmentalism and Institutional Change. Oxford: Oxford University Press.

Smith, M. E. 2004. "Toward a Theory of EU Foreign Policy-Making: Multi-Level Governance, Domestic Politics, and National Adaptation to Europe's Common Foreign and Security Policy." Journal of European Public Policy 11 (4): 740-758. doi:10.1080/1350176042000248124.

Stavrakakis, Y., and G. Katsambekis. 2014. "Left-Wing Populism in the European Periphery: The Case of SYRIZA." Journal of Political Ideologies 19 (2): 119-142.

Stavridis, S., C. Tsardanidis, and G. Christou. 2015. "The Impact of the International Financial and Economic Crisis on the (De)Europeanisation of National Foreign Policies in the Mediterranean." Hellenic Studies 23 (1). Accessed 23 February 2018. http://wrap.warwick.ac.uk/76147/1/WRAP_ 0484042-pais-260116-introduction_for_special_issue_hellenic_studies_final\%20\%281\%29.pdf

SYRIZA. 2015. “Foreign Policy Positions, Athens" January 2015. Accessed 24 June 2017. http:// www.SYRIZA.gr/theseis/pros_diavoulefsi_exoteriki_politiki.pdf

Tagliapietra, S., and G. Zachmann. 2015. Will Natural Gas Cooperation with Russia Save the Greek Economy? Brussels: Bruegel. Accessed 26 June 2016. http://bruegel.org/2015/04/willnaturalgascooperation-with-russia-save-the-greek-economy/.

Tsakiris, T. 2013. Cries and Whispers: Why Did the Russians Withdraw from the DEPA/DESFA Tender and What Does This Mean for Greece's Position in the Southern Corridor? Athens: ELIAMEP Briefing Note 20/2013. [in Greek].

Tsakiris, T. 2014. Greece and the Energy Geopolitics of the Eastern Mediterranean. London: LSE Ideas. Strategic Update 14.1.

Tsakonas, P. 2010. The Incomplete Breakthrough in Greek-turkish Relations: Grasping Greece's Socialization Strategy. London: Palgrave Macmillan.

Tsardanidis, C. 2015. "Greek Foreign Policy: The De-Europeanisation Impact of the Economic Crisis." Hellenic Studies 23 (1): 59-81.

Tsardanidis, C., and S. Stavridis. 2005. "The Europeanisation of Greek Foreign Policy: A Critical Appraisal." Journal of European Integration 27 (2): 217-239. doi:10.1080/07036330500097856. 
Voulgaris, G., and E. Nicolacopoulos. 2014. 2012. The Double Electoral Earthquake. Athens:Themelio (In Greek).

Wallace, Helen and William Wallace. 2007. 'Overview: The European Union, Politics and PolicyMaking.' In Handbook of European Union Politics, edited by K. E. Jorgensen, M. A. Pollack, and B. Rosamond, 339-358. London: Sage.

Wong, R., and C. Hill, eds. 2012. National and European Foreign Policies: Towards Europeanisation. New York: Routledge.

Zürn, M. 2004. "Global Governance and Legitimacy Problems." Government and Opposition 39 (2): 260-287. doi:10.1111/j.1477-7053.2004.00123.x.

Zürn, M. 2014. "The Politicization of World Politics and Its Effects: Eight Propositions." European Political Science Review 6 (1): 47-71. doi:10.1017/S1755773912000276.

\section{Appendix: Interviews}

1. Diplomat, FYROM mission to the EU, Brussels, 9 May 2016.

2. Energy policy expert, Brussels, 10 May 2016.

3. DG NEAR official, Brussels, 12 May 2016.

4. DG ENER official, Brussels, 12 May 2016.

5. EEAS official, Brussels, 13 May 2016.

6. EEAS official, Brussels, 14 May 2016.

7. EEAS official, Brussels, 31 May 2016.

8. Greek diplomat, Athens, 13 June 2016.

9. Greek energy policymaker, Athens, 14 June 2016.

10. Greek diplomat, Athens, 15 June 2016.

11. Greek foreign policy expert, Athens, 15 June 2016.

12. Greek diplomat, Athens, 16 June 2016.

13. EU diplomat, London, 8 May 2015. 